His treatise "Des Phenomènes d'Hybridité dans le Genre humain " appeared in 1858 and 1859 , and in 1864 was translated into English.

Among the great number of memoirs may further be mentioned: "L'Intelligence des Animaux et le Règne humain," "La prétendue Degénerescence de la Population française," a brilliant plea for the French nation, "L'Ordre des Primates: Parallele anatomique de l'Homme et des Singes," "Recherches sur l'Indice Nasal," "Étude sur la Constitution des Vertebres caudales chez les Primates sans Queue," "Les Troglodytes de la Vézère," "La Race Celtique ancienne et moderne," "Étude sur les Propriétés hygrométriques des Crânes," "Sur l'Origine et la Répartition de la Langue basque," "Recherches sur l'Indice orbitaire," "Sur l'Angle orbito-occipital."

The practical results of a good deal of Dr. Broca's anthropological researches are found in his "Instructions," forming two separate volumes ; one, for the anthropological study of the living, appeared for the first time in 1864 , and has been re-edited several times since; the other, particularly on craniology and craniometry, was published in 1875. Another valuable memoir is that on the "Indices de Largeur de l'Omoplate chez l'Homme, les Singes et dans la Série des Mammifères," in which he opened up new views on the comparative anatomy of races and mammals. One of Dr. Broca's last works was his important study on the "Variations craniométriques et de leur Influence sur les Moyennes," \&c.

The greatest glory of Broca is perhaps the foundation of the Anthropological Society of Paris in 1859. The perseverance and talent of the founder surmounted all the difficulties and troubles of every kind which threatened in the beginning the existence of the society, which now, after nearly one-and-twenty years, is flourishing as one of the first learned societies in Europe. During these long years Broca was the soul of the anthropological movement in France; nay, we may say that his influence extended far beyond his own country, and that the study of man in other civilised countries has been followed after his method. In reality Broca was at the same time the founder of a new and excellent anthropological school: his method of anthropometry, \&c., as expounded in the "Instructions" above-mentioned, is now followed by the great majority of anthropologists. But this was not enough for the indefatigable zeal of the eminent scholar; in 1872 he commenced to publish the Revus d'Anthropologie, one of the best organs on the science of man. Many of his own works have been published in it.

Broca's last and greatest work was the foundation in 1876 of the now celebrated École d'Anthropologie in Paris, with a first-rate museum, laboratories, library, and a complete course of anthropological lessons given by more than half-a-dozen professors, among whom are de Mortillet, Bertillon, and Topinard. Broca himself taught the comparative anatomy of the Primates.

The laboratories above-mentioned belong at the same time to the École pratique des Hautes Études since 1878 .

Broca, the scholar, philosopher, and statesman, died on the field of honour, in the midst of his work, in the vigour of life. Though dead, his work will never perish; man dies, but science remains. His illustrious example will continue to enlighten the path of those who follow the imperishable footprints he has left.

H. F. C. TEN KATE

\section{THE WOOLWICH GUNS}

$A$ PETITION signed by several men well known in the field of mechanical science and presented to the House of Commons last week contains many points to which it is important that public attention should be directed. The memorialists state their belief that the system of heavy ordnance now in use and known as the Woolwich system is inefficient and dangerous, that, con- sidering the increasing dependence of the nation for food supply upon its command of the sea, it is evidently unsafe to neglect any of the opportunities which the mechanical skill and manufacturing resources of the country afford for securing the best weapons of offence and defence for our fleet and our army; "that, having regard to the advances constantly being made by private manufacturers in this and other countries, and to the ordnance actually in use or in course of construction for the other Powers of Europe and America, your petitioners look with dismay upon the defects of the. English heavy guns, and they are of opinion that these defects seriously endanger our naval supremacy and our national safety." Further the petitioners maintain that it is not right that the heads of the manufacturing department, which is in competition with outside manufacturers, should be the official advisers of her Majesty's Government as regards new inventions, and that the defects in our present system of ordnance arise and are likely to continue from the absence of independent criticism, and in consequence of the technical advisers of the Government being the same persons as those who either are or have been in charge of the manufactories responsible for these defects; that there are in existence several systems of o1 dnance superior to the Woolwich system, and that it is of national importance that private establishments for the production of arms of all kinds should be encouraged and should not be crushed by giving a virtual monopoly to the Government establishments, but that the private trade and the Government factories should rather serve as reserves to one another.

The principal issues thus raised may be very shortly stated. If we want the best guns, can they be obtairred better from a Government manufactory carefully fenced round by official jealousy, or can a better article be procured by open competition amongst private manufacturers? Is it impossible for the technical advisers of the Government to select from the enormous mass of inventions and improvements offered to them those of real value? And further, do they, or would they make this selection if it were in their power? It has often been objected that the great quantity of suggestions and friendly advice constantly being received renders it quite impossible to treat them with adequate discrimination; but if the officials intrusted with this work were only possessed of a thorough scientific knowledge of mechanical principles, we believe that nine-tenths of the worthless schemes could be at once rejected, so inevitably does the mark of the circle-squarer appear in his work to one who knows where to look for it.

Respecting the remaining ro per cent. of inventions and improvements, it would probably require somewhat greater practical judgment to decide which were worth further investigation; but while we do not for a moment suggest that the whole of these should be examined and tested at the expense of the tax-payer, it is at least not too much to expect that an obviously good design should not be rejected with an official reply. Inventors are probably the most persevering of all men, and, fortunately for the cause of progress, though not perhaps for their own advantage, they have a greater belief than any one else in the results they hope to obtain; but it is hardly to be expected that they will bestow their whole powers of persuasion on the authorities of their own country when they plainly see a more open field abroad.

For instance, there can be little doubt that the Whitehead torpedo might have been a secret exclusively the property of this country if the inventor had been afforded a fair investigation; again, it would be interesting to know whether the Russian Government required as much persuasion to induce them to adopt the Moncrieff hydropneumatic gun-carriage as has been expended in bringing it as far as the "experimental" stage in our own service.

That many inventors have had a short innings at the 
hands of the War Department is to be plainly seen in the collections of what are merely regarded as useless eccentricities at Woolwich and Shoeburyness, but it is very improbable that most of the lessons to be learnt from these have ever been appreciated by those who were responsible for their rejection. Has it not taken twenty years for the system invented by Robert Mallet of building up a massive piece of ordnance capable of being taken to pieces to facilitate transport, to at length bring forth the present seven-pounder screw gun, which can be carried in halves on the backs of mules? It would be interesting to know whether any private firm in this country, if they had received the order, could have manufactured and proved a train of siege guns on similar principles, and capable of as easy transport as the modern field gun, and which would have considerably facilitated Gen. Stewart's advance to Cabul.

It can of course be urged with some show of reason that, considering the enormous supply of most patterns of guns and the vast quantity of ammunition required throughout the Empire, great inconvenience would result from too great a multiplicity of designs; but to continue the manufacture of an inferior pattern for this reason when a better one is procurable appears to us only to make the evil greater when the former has to be finally abandoned as obsolete. Thus we suppose it must have been obvious to a great many persons for the last five years that the days of heavy muzzle-loading guns for the navy were numbered, from the difficulty or impossibility of giving sufficient length of bore for the consumption of large charges of powder while still enabling the gun to be fought in a turret. All possible ingenuity was then expended on shortening the recoil and on mechanical systems of loading in a confined space, with results that might have been incalculably disastrous had this country been involved in war previous to the terrible accident on board the Thunderer; all this too while we believe a suitable pattern of breech-loader was in the hands of a private firm and had been tendered by them for adoption by the War Department. If it could be shown that a Government factory could alone turn out guns of the best manufacture, superior to anything that could be produced by private establishments, the logical sequence would be that armour plates and marine engines and the ships themselves should all be provided in the same way.

The effect of a Government monopoly on the foreign trade of a manufacturer is too well known to require demonstration; but if the encouragement of private establishments for the production of all kinds of arms and warlike stores should result, as it doubtless would, in a larger trade with foreign powers in these manufactures, while we should profit by their custom in time of peace, they would not only find themselves in the event of war with this country cut off from their supply of fresh arms and ammunition, but the whole of our own increased production would be available for national defence.

If such an inquiry as is sought for in this petition be instituted by the present Government, conducted not only by officers of the army and navy, but also under independent scientific advice, we believe that numerous articles of belief and revered principles of construction will be shown to have been long exploded and will have to be at once abandoned. We shall then probably find the Woolwich system of rifling with increasing pitch and studded projectiles giving place to the poly-groove of uniform pitch with rotation by gas-check which has been under consideration for years, and is yet scarcely recognised ; we may even take a hint from the Chinese Government, who, by applying to Sir William Armstrong's firm, have for more than a year been in possession of four more powerful guns than any afloat in our most recent ironclads; we should perhaps find that a system of breech-loading is ready for adoption solving most of the difficulties of turret and casemate defence, and that a trustworthy type of hammered steel is ready at hand to be substituted for the welded coils of wrought iron at present in use.

If it should be found that our Government establishments have been suffering from a slow process of crystallisation, they might be resuscitated by being placed in keen competition with private firms whose very existence depends on their unceasing activity, or at the least it would be ascertained whether in a critical time the country would have to depend entirely on the Royal Gun Factory, or whether some of the old firms who in former years fought so hard for a share in the work have not forgotten their skill.

\section{LIVING ON WATER}

H OW long a man can live on water alone is now the subject of an experiment in New York. A Dr.

Tanner from Minnesota is devoting himself to this trial. Tanner declares that he can live for forty days without food, and is proving, or trying to prove, the truth of the hypothesis on his own unfortunate person. He is reported to have got through twenty-eight days of his endeavour, and still to be alive and comparatively well. On the twentieth day his pulse was 76 , his temperature 98.405 , and his actual weight 132 lbs. On the twentyeighth day his weight was 130 lbs. He lost $27 \frac{1}{2}$ lbs. in the first nineteen days during which he fasted, and then ceased to waste at the same rate. The latest report we have of him states that he is cheerful, active, and, notwithstanding abundant medical opinion to the contrary, confident that he should continue to the end of the time named for the experiment. Of food of the solid kind he touches none ; of drink he partakes of water and nothing else; water and air will, he maintains, sustain him; and that notwithstanding exertions from riding and other exercises. Dr. Tanner is not original in this mode of attempt upon his own life. In the Transactions of the Albany Institute for 1830 Dr. McNaughton reported the history of a man named Reuben Kelsey, who on July 2, I829, declined eating altogether, assigning as a reason "that when it was the will of the Almighty that he should eat he would be furnished with an appetite." McNaughton's account of this man is singularly interesting. We have not room for all the details, but it may be told in brief that Kelsey continued to live for fifty-three days; that he went out of doors and walked about during the greater part of the time, and that he was able to sit up in bed until the last day of his life. During the first three weeks of his abstinence he fell away very fast, but afterwards did not seem to waste so sensibly. Towards the close of his days the colour of his flesh was blue, and at last blackish. His skin was cold, and he complained of chilliness. His general appearance was so ghastly that children were afraid of him. Of this he himself seemed to be aware, for it was not uncommon to observe him covering his face when strangers were passing by. At the time of his deatb Mr. Kelsey was twentyseven years of age. The writer of this notice once attended a gentleman, who, for a nearly similar reason as that assigned by Mr. Kelsey, abstained from all food, except water, for even a longer period, viz., fifty-five days. In this instance the wasting was most obscrved in the first three weeks of the fasting. From this it will be gathered that Dr. Tanner may live to the full extent of forty days on water without being suspected of having been the subject of a miracle. It is against the success of his experiment that he should be exposed to an amount of excitement and vexation that must reduce greatly the vital power, but for all that he may possibly survive the ordeal. The grand question is how he will cry back again. The facts of these examples, painful as they are, are not without their use. They indicate that water being admitted into the body, life may go on for periods 